\title{
Regulatory mechanisms of microRNAs in lung cancer stem cells
}

\author{
Tao Fan, Wei Wang, Boyou Zhang, Yao Xu, Lei Chen, Shize Pan, Hao Hu and Qing Geng *
}

\begin{abstract}
Increasing evidence suggests that cancer stem cells (CSCs) are a key occurrence in the process of many human cancers. Lung cancer is the most common aggressive malignancy and cause of cancer death worldwide. The research on lung cancer stem cells has been highlighted for many years. Lung CSCs seem to play a major role in lung cancer metastasis, drug resistance and tumour-self-renewal. MicroRNAs (miRNAs), a class of newly emerging small noncoding RNAs that act as post-transcriptional regulators of gene expression, have been demonstrated to serve as a vital player in fine-tuning a number of biological activities ranging from embryogenesis to programmed cell death as well as tumourigenesis. In recent years, several miRNAs have been highlighted to be specifically expressed in CSCs. The miRNA profile of CSCs is remarkably different from non-stem cancer cells. As such, many miRNAs have been shown to regulate self-renewal and differentiation properties of CSCs. In this review, we present the latest findings on miRNAs that regulate the tumour microenvironment of lung CSCS with the goal to prompt the development of novel therapeutic strategies for patients with lung cancer.
\end{abstract}

Keywords: MicroRNAs (miRNAs), Lung cancer stem cells (LCSCs)

\section{Background}

Lung cancer is the leading cause of cancer deaths and the most common aggressive carcinoma worldwide (Ferlay et al. 2010; Papagiannis 2004). The research on oncotherapy has been highlighted for more than half a century. Accurately understanding the molecular biology of cancer is the only possibility for conquering lung cancer. During the past 20 years, the discovery and study of miRNAs has provided a new approach for the treatment of cancer. Since Lee et al. (1993) and Reinhart et al. (2000) first identified miRNAslin-4 and let-7controlling the developmental timing in nematode Caenorhabditiselegans, extensive studies have been conducted to discover the functional role of miRNAs in multiple biological activities, ranging from embryonic development to cell death (Fabian and Sonenberg 2012; Pauli et al. 2011; Rinn and Chang 2012), and from cancer formation to its development (Li et al. 2009; Wang et al. 2013b; Ohashi et al.

\footnotetext{
*Correspondence: szgqing@126.com
}

Department of Thoracic Surgery, Renmin Hospital of Wuhan University, Wuhan 430060, China
2011; Pang et al. 2010c; Rachagani et al. 2010; Kurisetty et al. 2014; Serpico et al. 2014; D'Ippolito and Iorio 2013).

Since Mackillop (Mackillop et al. 1983) first put forward the hypothesis of cancer stem cell theory, the overwhelming mass of research has infiltrated into the characterization of cancer stem cells (CSCs) from different tumours (Chhabra and Saini 2014). The cancer stem cell hypothesis is based on a theory that cancer has a hierarchical cell structure in which only a subpopulation of cells, termed cancer stem cells (CSCs), which have the ability to regulate self-renewal and differentiation of cancer cells, are able to initiate tumour formation. In addition, they also fine-tune tumour metastasis by altering genetic signalling pathways (Pang et al. 2010a; Hermann et al. 2007). Lung CSCs, which have the characteristics of self-renewal and differentiation, were first isolated from the junction between the rat bronchioles and alveolar ducts by Kim in 2005.

miRNAs are short (20- to 24-nucleotide), small and non-coding single-stranded RNA molecules that can inhibit gene expression by conducting target mRNA degradation or translational repression. Its molecular mechanism is that primary miRNAs (primiRNAs), which 
are transcribed by RNA polymerase II or III with $5^{\prime}$-end caps and $3^{\prime}$-end poly-A tails (Borchert et al. 2006; Lee et al. 2004; Cai et al. 2004), bind to the $3^{\prime}$-untraslated regions ( $3^{\prime}$ UTRs) or the open reading frames of target genes to influence expression of mRNA. miRNAs regulate gene expression. It has been demonstrated that miRNAs inhibit gene translation in a proliferating state but stimulate it in a quiescent state (Vasudevan et al. 2007; Bartel 2004; Garzon et al. 2009). It can be summarized that miRNAs participate in a series of biological processes including cell proliferation, apoptosis, the immune response and differentiation of CSCs (Dumortier et al. 2013; Hwang and Mendell 2006; Chivukula and Mendell 2008; Esau et al. 2004; Zhao et al. 2010; DeSano and Xu 2009; Perera and Ray 2007) by intervening with biological signals of transcription, nuclear processing, exportation, and cytoplasmic processing, as well as inhibiting or activation translation (Bartel 2004; Garzon et al. 2007, 2009; Liu and Tang 2011). Abundant expression of miRNAs has also been found in CSCs. Since Lee et al. (1993), Reinhart et al. (2000) first identified miRNAs regulating stem cells in Caenorhabditiselegans, cancer research has stepped into a new stage in recent years. If the CSC hypothesis is true, then deletion of CSCs would be a perfect treatment, and the aberrant expression profile of miRNAs may be the cause of the initiation and development of the tumour (Lobo et al. 2007). Therefore, regulating expression of miRNAs would be a new target to treat cancer. This aspect, however, needs further study.

\section{miRNAs IN LUNG CSCs}

An increasing number of miRNAs have been confirmed to be involved in self-renewal and metabolism of lung CSCs. miRNA-145 was found to be expressed at low levels in lung adenocarcinoma (LAD)-associated CSCs and was further validated to inhibit the proliferation of LAD-CSCs and be negatively correlated with the levels of Oct4/Sox $2 /$ Fascin 1 in LAD patient specimens (Chiou et al. 2012; Zhang et al. 2011; Hu et al. 2014). In two other studies on lung adenocarcinoma CSC, let-7and miR-31 were significantly down-regulated in side population (SP) cells, which are an enriched source of CSCs, compared to non-SP cells (Hua et al. 2012). Interestingly, these two miRNAs play opposing roles to maintain a balance between differentiation and quiescence of LAD-CSCs. A previous study showed that miRNA-200b is significantly down-regulated in $\mathrm{CD} 133^{+} / \mathrm{CD} 326^{+}$cells, which exhibit characteristics of CSCs derived from docetaxelresistant LAD cells. These findings strongly suggest that aberrantly expressed miRNAs, such as miR-29ab, miR183 , and miR-127-3P, play significant roles in regulating the CD133+/CD326+ subpopulation of cells (Lin et al. 2012). Therefore, miRNAs could substantially affect the biobehaviours of LCSCs, including cell cycle, proliferation, apoptosis, immune response and differentiation, by controlling the signalling pathways of LCSCs. Here, we present the latest findings on miRNAs that regulate the tumour microenvironment of lung CSCs to prompt the development of novel therapeutic strategies for patients with lung cancer (Table 1). Figure 1 shows the potential therapeutics of miRNAs in LCSCs.

\section{miRNA-145 regulates lung CSCs}

miRNA-145 is an important regulator of tumourigenesis. Previous research by Cho WC demonstrated that miRNA-145 inhibited cell proliferation of human lung adenocarcinoma by targeting EGFR and NUDT1 (Cho et al. 2011). Lu et al. (2014) further found that mirRNA-145 functions as a tumour suppressor and targets two oncogenes, ANGPT2 and NEDD9, in renal cell carcinoma. In recent years, it has been shown that mirRNA-145 is down-regulated in lung adenocarcinoma tissues and negatively correlates with the expression of Oct4 (Yin et al. 2011), which is expressed in lung CSCs $\left(\mathrm{CD} 133^{+}\right.$cells) (Hu et al. 2014). The precise molecular mechanism of mirRNA-145 in lung CSCs is not known. A previous study indicated that miRNA-145 reduced the capacity of proliferation, invasion and tumour sphere growth in lung adenocarcinoma-initiating cells. Epithelial-mesenchymal transition (EMT), which regulates a dedifferentiation programme that converts adherent epithelial cells to individual migratory cells, plays an important role in regulating embryonic development, cancer migration, and tumour metastasis (Kalluri and Weinberg 2009; Thiery 2002), which is similar to CSCs (Pirozzi et al. 2011). Dai et al. (2013) confirmed that the EMT process of colorectal cancer cells was regulated by Oct4, an important transcriptional factor that has been proposed as a biomarker of cancer-initiating cells (CICs). $\mathrm{Hu}$ et al. (2014) further verified the amazing effect of miR-145 on properties of lung CSCs and EMT in vivo by regulating Oct4. It has been reported that cationic polyurethane-short branch polyethylenimine (PU-PEI) exhibits high transfection efficiency with relatively low cytotoxicity (Hung et al. 2009; Liu et al. 2009) and has been shown to be a deliverer for overexpression of Oct4 and SirT1 in the process of reprogramming aged retinal pigmented epithelium cells into progenitor-like cells and rescuing light-induced retinal cell loss and dysfunction (Peng et al. 2011). Guang-Yuh and his colleagues found that LAD patients with a microRNA- $145^{\text {low }}$, Oct $4^{\text {high }}$, Sox $2^{\text {high }}$, or Fascin $1^{\text {high }}$ phenotype had a poor prognosis and outcome, and microRNA-145 was proven to be the most relevant marker (Chiou et al. 2012). As a vehicle formicroRNA-145 delivery, PU-PEI mediates miR-145 overexpression and inhibits the properties of 


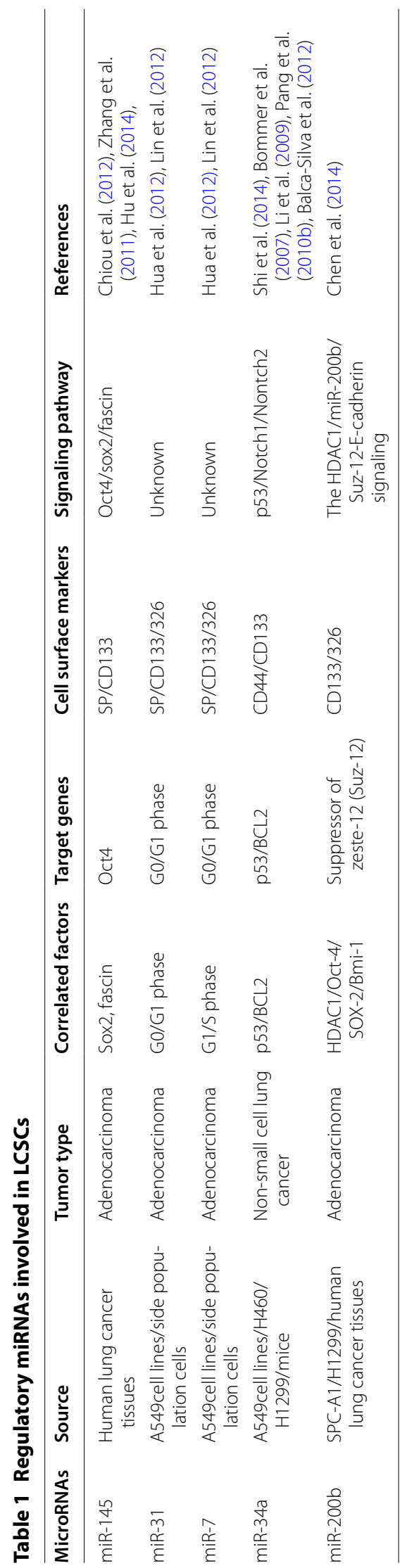




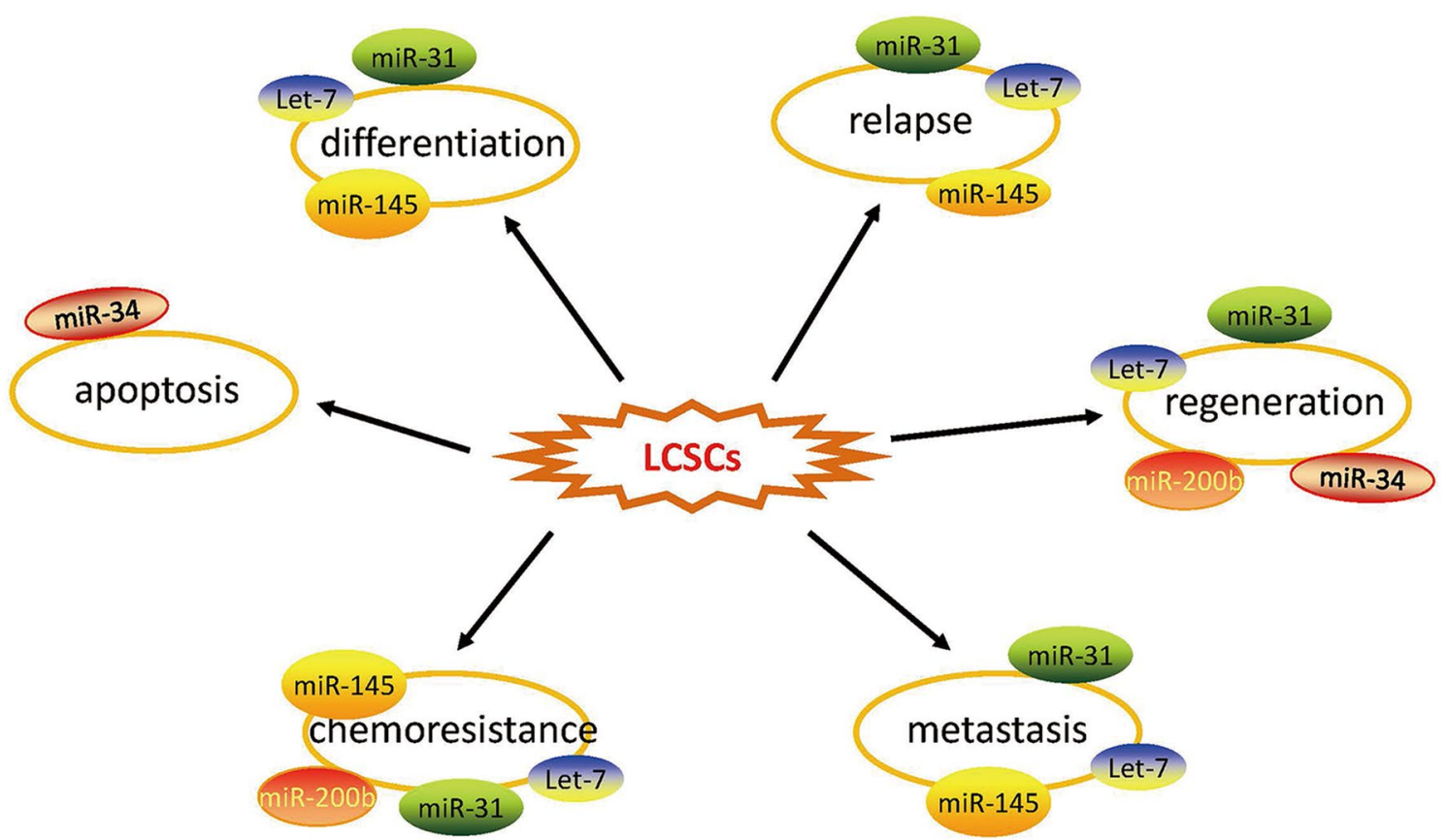

Fig. 1 The different miRNAs regulate properties of lung cancer stem cells (LCSCS). By targeting a variety of downstream signalling pathways, several miRNAsact synergistically to regulate several key biological properties of LCSCs including differentiation, relapse, regeneration, metastasis, chemoresistance and apoptosis

LAD-CSCs by repressing its downstream targets, Oct4, Sox2, and Fascin1 (Chiou et al. 2012), which provides a novel miRNA-based approach for the treatment of LAD by artificially enhanced expression of microRNA-145 (Fig. 2).

\section{MicroRNA-31 and let-7 regulate lung CSCs}

Encoded by a single genomic locus, microRNA-31 is expressed in a variety of tissues and cell types (Grimson et al. 2007; Landgraf et al. 2007). Altered expression of miR-31 has been verified in various human tumours

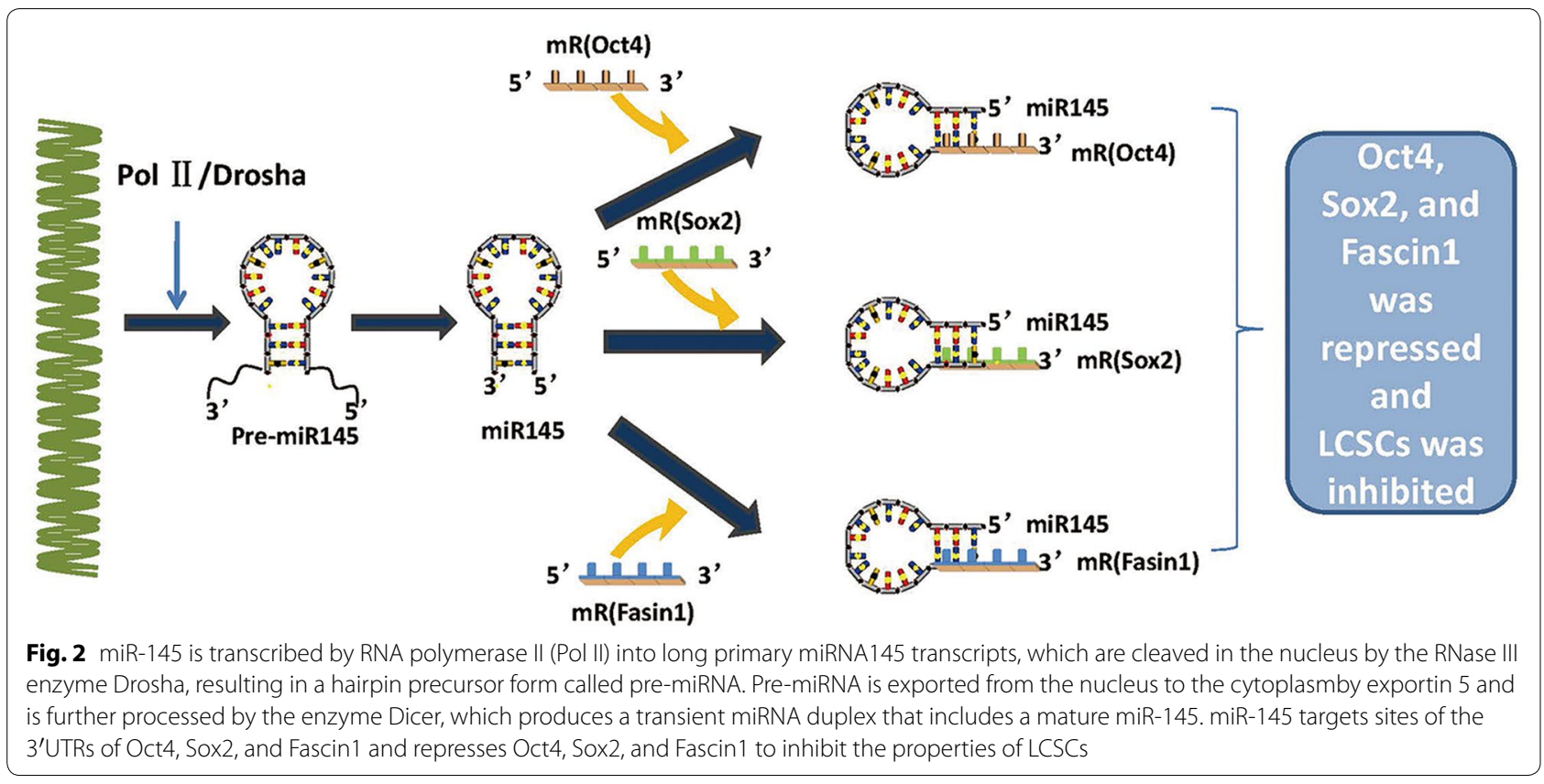


(Valastyan and Weinberg 2010). It is reported that miR31 levels are inversely associated with the propensity to suffer metastatic relapse in primary human breast tumours (Valastyan et al. 2009b). Similarly, down-regulation of miR-31 was observed in human bladder carcinomas with an invasive phenotype (Wszolek et al. 2011). Valastyan et al. (2009a) has stated that miR-31 impairs more than three distinct steps of the invasion-metastasis cascade: local invasion, one or more early post-intravasation events (intraluminal viability, extravasation, and/or initial survival in the parenchyma of distant tissues), and metastatic colonization (the outgrowth of micrometastases into macroscopic secondary lesions). The let-7 family, one of the most highly up-regulated families of miRNAs, consists of 12 members located in genomic locations frequently deleted in human cancers (Calin et al. 2004). The let-7 family targets several key genes in the PI3K/AKT/insulin pathway during cardiac maturation (Kuppusamy et al. 2015). The early research on let-7 in the field is about energy metabolism (Zhu et al. 2011; Frost and Olson 2011). In recent years, it has been reported that let- 7 was down-regulated in several cancers (Johnson et al. 2005; Mayr et al. 2007; Sampson et al. 2007). Johnson et al. (2005) found that expression of let-7 RNA is reduced in non-small cell lung cancer patients and is associated with poor prognosis. In addition, overexpression of let-7 reduces tumour burden in a K-Ras murine lung cancer model (Sampson et al. 2007). SP cells are a rare cell population that are an enriched source of stem cells in some normal tissue and intumours, such as glioma, colorectal, ovarian cancer and lung cancer tumours (Kondo et al. 2004; Brown et al. 2007; Szotek et al. 2006; Ho et al. 2007; Larderet et al. 2006). Under differentiating conditions, SP cells can differentiate into non-SP cells and lose their stemlike properties (the ratio of SP gradually decreases with culture time) (Hua et al. 2012). It has been confirmed that microRNA-31 and let-7 are significantly down-regulated in lung SP cells (lung CSCs). Interestingly, Hua et al. (2012) found that low expression of let-7 was the key to the preservation of their ability to proliferate, and low expression of microRNA-31 was necessary for their undifferentiated status to persist. It can be confirmed that the reduced expression of let-7 and microRNA31were critical for SP cells to preserve their stemness. MicroRNA-31 acts as an oncogenic gene, while let-7 functions as a lung cancer suppressor microRNA (Johnson et al. 2007; Liu et al. 2010), which suggests that miR-31 and let-7 have opposite functions on lung CSCs. Antisense oligonucleotide transfection experiments have supported this view by cell cycle research that showed that reduced miR-31 could inhibit cell proliferation by a cell cycle arrest in the G0/G1 phase, whereas reduced let-7 induced cell proliferation by accelerating the G1/S phase transition (Hua et al. 2012; Fig. 3). As regulators for maintaining the balance between differentiation and quiescence for SP cells, let-7 and microRNA-31 would be novel endogenous lung CSC targets to treat lung cancer.

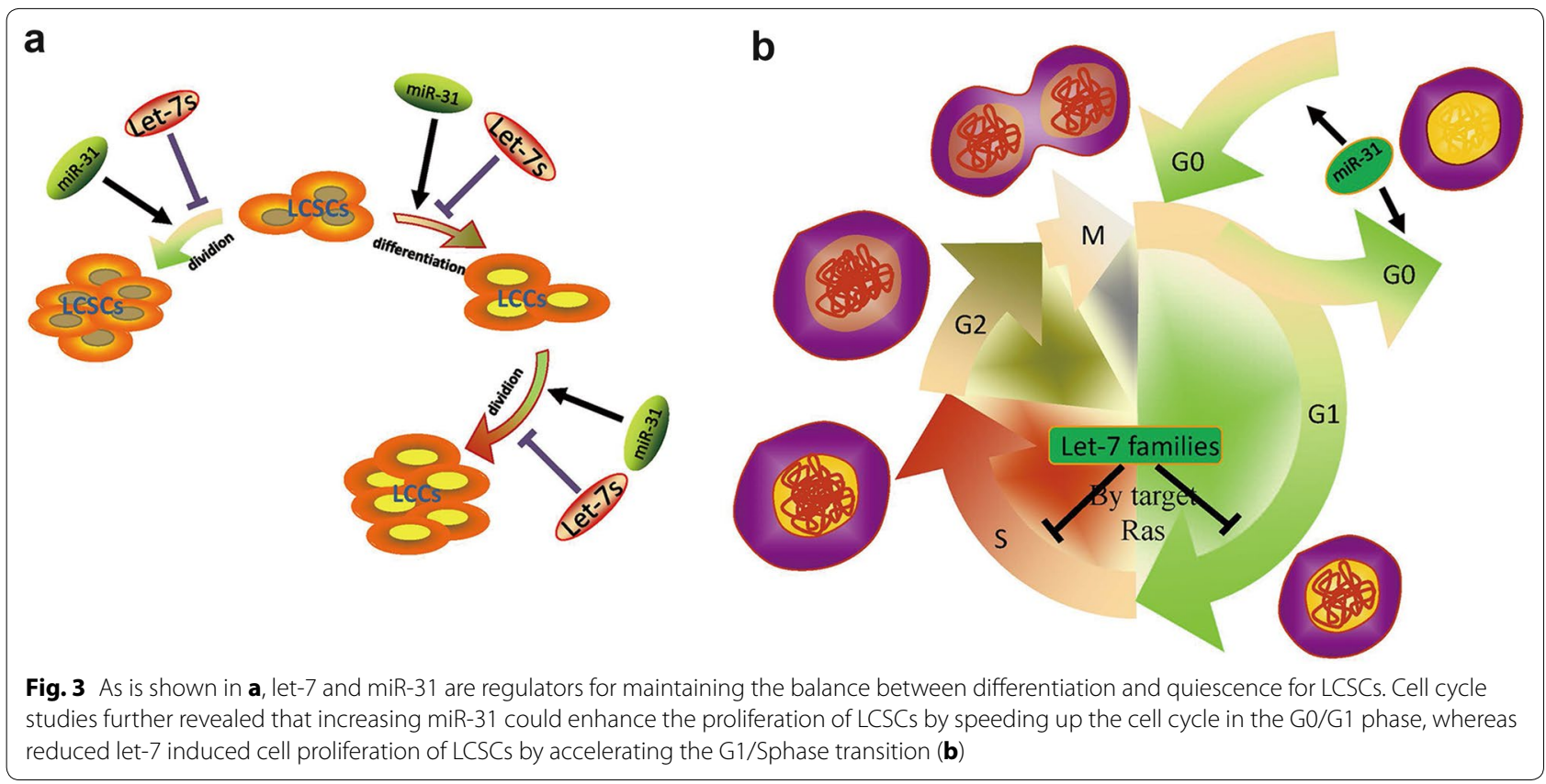




\section{miRNA-34a regulates lung CSCs}

The miRNA-34 family, which is composed of miR-34a, miR-34b, and miR-34c, is confirmed to be involved in the p53 and Notch signalling pathways (Shi et al. 2014; Bommer et al. 2007; Li et al. 2009; Pang et al. 2010b; BalcaSilva et al. 2012; Fig. 4). Pang et al. have demonstrated that miRNA-34a binds to the 3 -untranslated regions of Notch1 and Jagged1. miRNA-34a is a tumour suppressor gene (Chen and $\mathrm{Hu}$ 2012) and inhibits abnormal cell growth, such as that in pancreas, melanoma, lung, breast, prostate, osteosarcoma, and gliomatumours ( $\mathrm{He}$ et al. 2009; Poellinger and Lendahl 2008; Yang et al. 2013; Liu and Tang 2011; Yan et al. 2012; Wiggins et al. 2010; Bandi and Vassella 2011). However, miR-34b/c, which has been identified in cases of malignant melanoma and glioma, may have the opposite function (Wu et al. 2013). With the research on the CSC hypothesis, the miR-34 family has now been shown to affect major properties of CSCs. Liu et al. (2011) have shown that miRNA-34a can inhibit prostate CSCs by directly repressing CD44. In another instance, enforced expression ofmiR-34 inhibited the self-renewal capacity of CD44C/CD133C pancreatic CSCs through the directdown-regulationofBcl-2and Notch signalling pathways (Wang et al.
2006). Furthermore, miRNA-34a was demonstrated to inhibit NSCLC cell holoclone formation and clonogenic expansion in vitro and even to repress tumour regeneration in vivo (Shi et al. 2014), which are due to its effects on stem-like NSCLC (NSCLC-CSCs). Further study verified that enhanced expression of miRNA-34a in CD44 ${ }^{\text {hi }}$ H460 cells greatly inhibited their tumour-regenerating activity. On the contrary, antagonists of miR-34a dramatically promoted tumour regeneration in $\mathrm{CD} 44^{\mathrm{lo}} \mathrm{H} 460$ cells. Similarly, these observations are confirmed in prostate and lung cancer (Wang et al. 2013a). In addition, the lower expression of miR-34a was considered to be a key aetiologic factor contributing to the aggressive behaviour of lung cancer stem cells (CSC), and thus, those features were mitigated by exogenous delivery and restoration of miR-34a activity (Basak et al. 2013). Taken together, as a regulator of the tumour-initiating capacity in NSCLC-CSCs, restoration of miR-34 levels may be used as a cancer therapeutic by down-regulating the Notch family members or target genes. The replacement of oncosuppressor miRNAs provides an effective strategy against tumour heterogeneity, and the selective RNAbased delivery system seems to be an excellent platform for a safe and effective targeting of tumours (Misso et al.
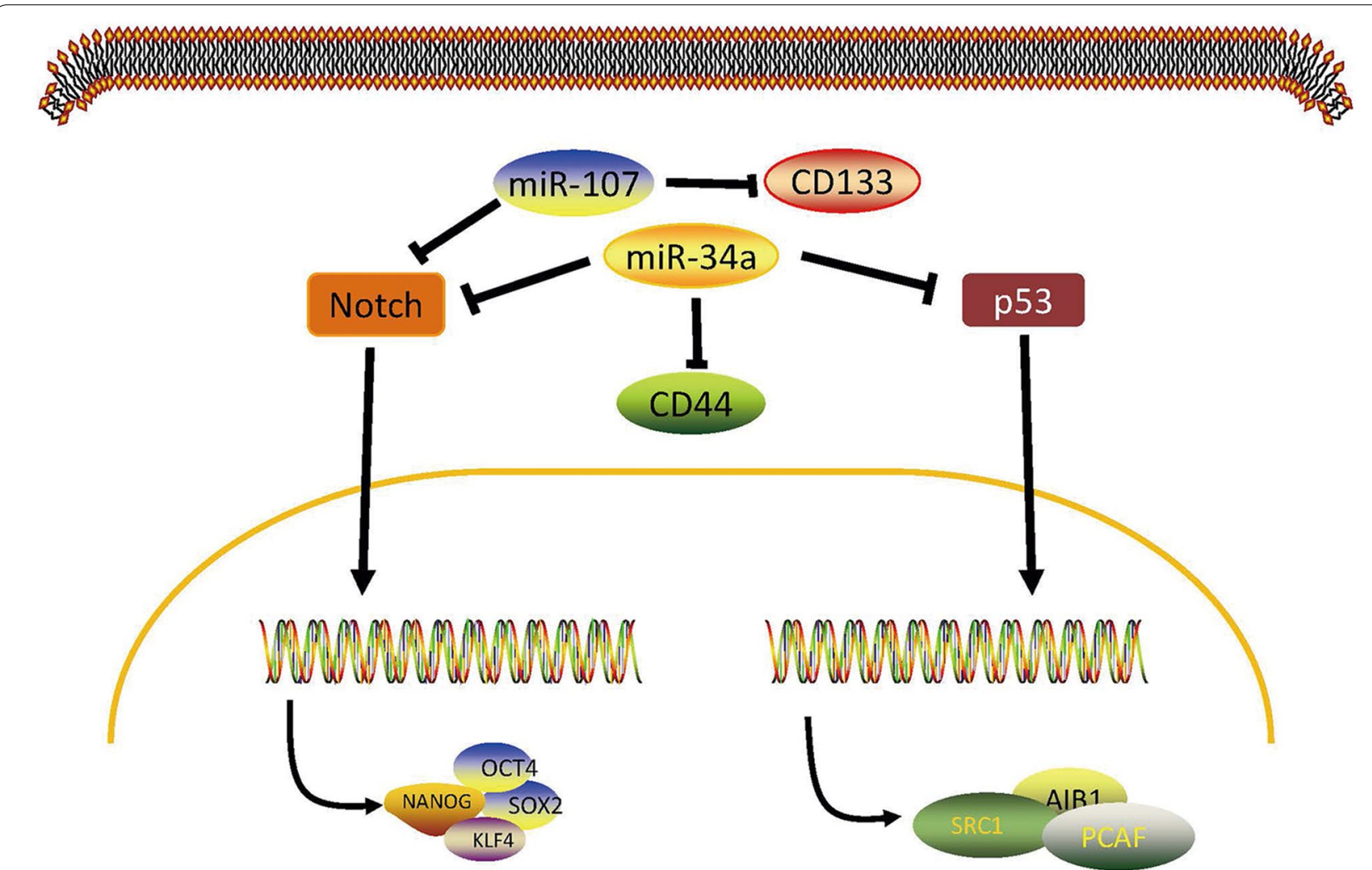

Fig. 4 miR-34a is a direct transcriptional target of $p 53$ and is a negative regulator of the tumourigenic properties of CD44 ${ }^{\text {hi }}$ lung CSCs. As is shown above, over expression of miR-34a could inhibit regeneration of LCSCs by repressing CD44 and the Notch and p53 pathways 
2014). Future work will aim to further clarify the underlying mechanisms and intervene in its signalling pathways to find a cure for cancer.

\section{miRNA-200b regulates lung CSCs}

Located at the miRNA-200b/c/429 gene cluster, miRNA200b, as an important member of miRNA-200 families, has the capability of repressing CSC growth and reversing the EMT phenotype of CSCs (Iliopoulos et al. 2010; Sun et al. 2012). The miRNA-200 family plays a key role in determining the epithelial phenotype by targeting zinc-finger transcriptional repressors ZEB1 or ZEB2 (Comijn et al. 2001; Gregory et al. 2008; Park et al. 2008). In recent years, miR-200b was demonstrated to be a key regulator of chemoresistance and restoration and has been shown to significantly reverse chemoresistance of docetaxel (DTX)-resistant (lung adenocarcinoma) LAD cells by inducing cell cycle arrest and apoptosis enhancement (Feng et al. 2012). Chen et al. (2014) first showed that miR-200b functions as a tumour suppressor in LAD CSCs both in vitro and in vivo. With further study, they demonstrated that histone deacetylase 1 (HDAC1) is involved in silencing of miR-200bthrough a Sp1-dependent mechanism. Inhibition of HDAC1 could induce miR-200b expression, which significantly suppresses maintenance of CSCs and reverses chemoresistance of CSCs by regulating Suz-12-E-cadherin signalling (Chen et al. 2014). CSCs have already been associated with chemotherapeutic failure in a variety of solid tumours. HDAC1/miR-200b/Suz-12/E-cadherin, which is involved in the regulation of CSC self-renewal, maintenance, tumourigenicity, growth and chemoresistance, may be the key regulatory network in regulating CSC maintenance and chemoresistance in human LAD cells (Fig. 5). This discovery will provide a novel strategy for reversing chemoresistance of human LAD.

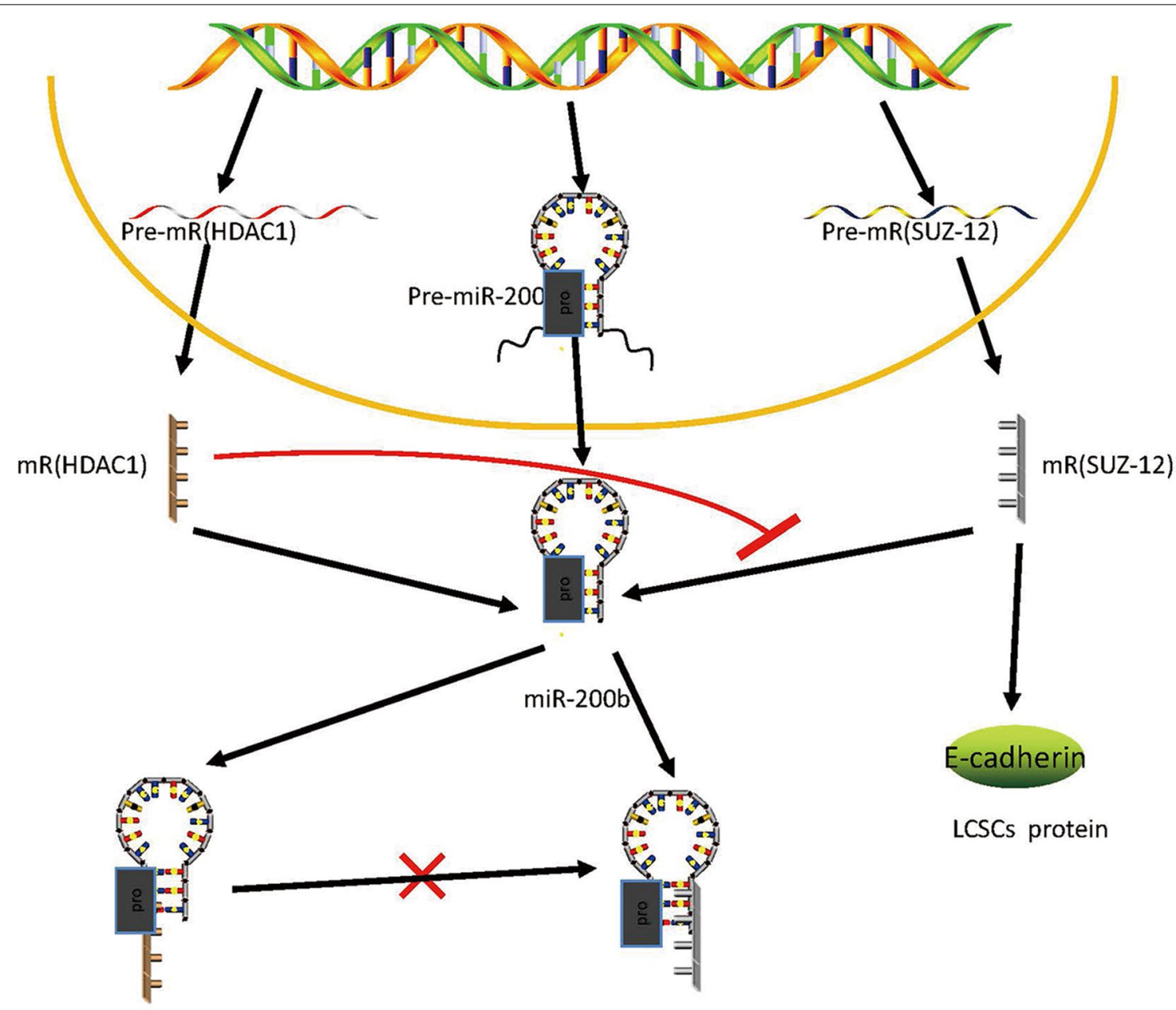

Fig. 5 Suppressor of zeste-12 (Suz-12) was identified as a direct and functional target of miR-200b. Histone deacetylase (HDAC) 1 repressed miR$200 \mathrm{~b}$ through a specificity protein (Sp) 1-dependent mechanism in which HDAC1 and Sp1 could bind to the miR-200b promoters (pro). Restoration ofmiR-200b by HDAC1 repression significantly suppressed CSC formation and reversed chemoresistance of CSCs by reducing Suz-12-E-cadherin 


\section{Conclusions and perspectives}

By targeting mRNAs for translational repression or degradation, miRNAs play important regulatory roles in animals and plants. As one of the most abundant classes of gene regulatory molecules in organisms, miRNAs likely influence the output of many protein-coding genes (Bartel 2004). There is mounting evidence to suggest that miRNAs are involved in many fundamental cellular processes such as cell differentiation, proliferation, apoptosis, carcinogenesis and cancer progression (Winter et al. 2009; Joshi et al. 2014). Correlated with characteristic clinicopathological parameters in cancer subtypes and existing not only in tissue but also in body fluids, microRNAs are potential biomarkers for different cancer subtypes classified by origin, histology, or chemosensitivity (Lu et al. 2005; Gilad et al. 2008; Kishikawa et al. 2015; Hollis et al. 2015). Due to their characteristic nature, microRNAs have a potential to be used for the development of diagnostics, prognostics, and targeted therapeutics.

In this review, the putting forward of the CSC theory gives researchers new ideas for recognizing the initiation of cancer and the regulation of cellular signalling in cancer and CSCs. Doubtless, CSCs do exist in tumours and drive tumour growth. Deeper research into CSCs will be a key to overcoming cancer. We have presented several regulatory mechanisms in CSCs, which mainly include miRNAs. In fact, since miRNAs were discovered in the 1990s, they have been increasingly confirmed to play a critical role in carcinogenesis and cancer regulation. As there have been aberrant miRNA expression profiles identified in lung cancer, miRNAs could potentially be used as biomarkers in the diagnosis and classification of lung cancer instead of helical computed tomography (CT) or even pathological examination. Despite the fact that inspiring progress has been achieved in miRNAmediated gene activation, many questions remain to be further elucidated. For example, we do not know if different miRNAs interfere with each other in regulating tumour genesis and cancer progression. Moreover, the research in the CSC field is at an early stage. The specificity and accuracy of lung CSC-associated miRNA signatures need to be studied further.

This review aimed to summarize recent achievements in research on miRNAs regulating lung cancer stem cells. Accumulating evidence indicates that miRNAs play critical roles in lung CSCs. They can effectively control lung cancer stem cell cycles, proliferation, apoptosis, immune response and differentiation by regulating the signalling pathways of LCSCs. miR-145 can suppress the cancer stem cell-like properties of LCICs and the EMT process by targeting Oct4. Additionally, let-7 and microRNA-31 are critical for
SP cells to preserve their stemness, as it was revealed that reduced miR-31 could inhibit cell proliferation by a cell cycle arrest in the G0/G1 phase, whereas reduced let-7 induced cell proliferation by accelerating the G1/S phase transition.miR-34a over expression inhibits NSCLC cell holoclone formation and clonogenic expansion in vitro and, importantly, tumour regeneration in vivo. The novel HDAC1/miR-200b/Suz-12/Ecadherin pathway was confirmed to play an essential role in regulating maintenance, tumourigenicity and chemoresistance of CSCs in human LAD. However, further studies are needed for a more detailed understanding of the role of miRNAs in the biology of lung CSCs. The future further insights into the molecular mechanisms of tumourigenesis will provide novel treatment strategies for patients with lung CSCs.

\section{Authors' contributions}

All authors contributed in the writing of this paper. In addition, TF was responsible for writing the manuscript. QG edited the manuscript. WW, BZ, YX, SP, $\mathrm{LC}$ and $\mathrm{HH}$ participated in its design and helped to draft the manuscript. All authors read and approved the final manuscript.

\section{Acknowledgements \\ This work was supported by grants received from the National Natural Science} Foundation of China (Grant No. 81170076 to G.Q)

\section{Competing interests}

The authors declare that they have no competing interests.

Received: 17 January 2016 Accepted: 28 September 2016 Published online: 10 October 2016

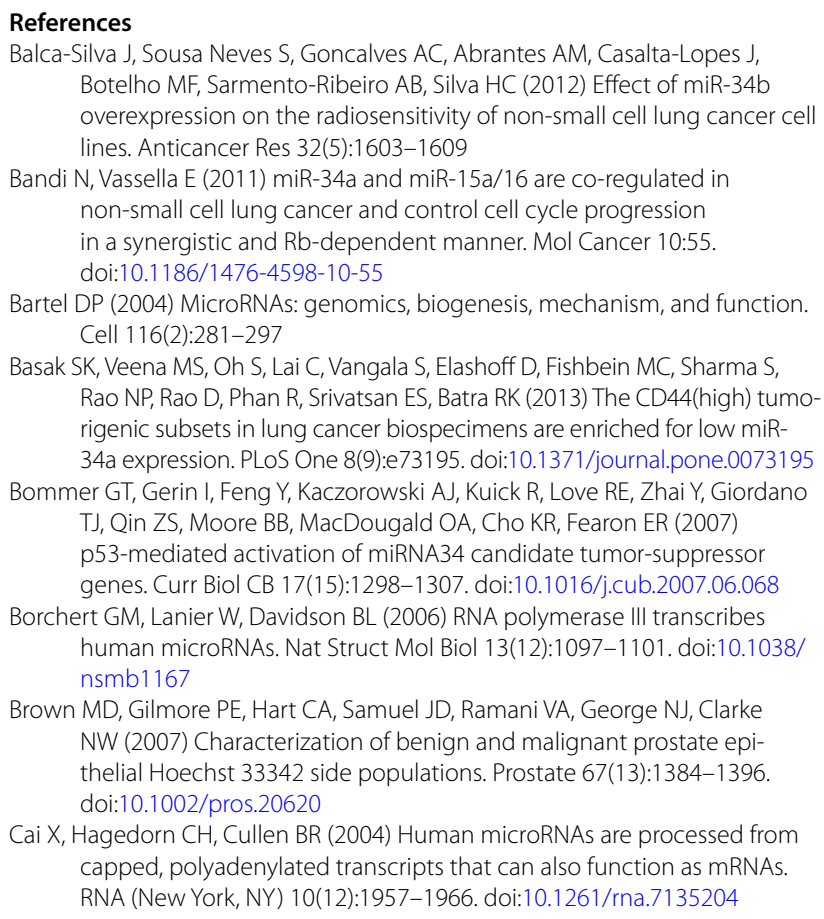
Botelho MF, Sarmento-Ribeiro AB, Silva HC (2012) Effect of miR-34b overexpression on the radiosensitivity of non-small cell lung cancer cell lines. Anticancer Res 32(5):1603-1609

Bandi N, Vassella E (2011) miR-34a and miR-15a/16 are co-regulated in non-small cell lung cancer and control cell cycle progression in a synergistic and Rb-dependent manner. Mol Cancer 10:55. doi:10.1186/1476-4598-10-55

Bartel DP (2004) MicroRNAs: genomics, biogenesis, mechanism, and function. Cell 116(2):281-297

Basak SK, Veena MS, Oh S, Lai C, Vangala S, Elashoff D, Fishbein MC, Sharma S, Rao NP, Rao D, Phan R, Srivatsan ES, Batra RK (2013) The CD44(high) tumorigenic subsets in lung cancer biospecimens are enriched for low miR34a expression. PLoS One 8(9):e73195. doi:10.1371/journal.pone.0073195

Bommer GT, Gerin I, Feng Y, Kaczorowski AJ, Kuick R, Love RE, Zhai Y, Giordano TJ, Qin ZS, Moore BB, MacDougald OA, Cho KR, Fearon ER (2007) p53-mediated activation of miRNA34 candidate tumor-suppressor genes. Curr Biol CB 17(15):1298-1307. doi:10.1016/j.cub.2007.06.068

Borchert GM, Lanier W, Davidson BL (2006) RNA polymerase III transcribes human microRNAs. Nat Struct Mol Biol 13(12):1097-1101. doi:10.1038/ nsmb1167

Brown MD, Gilmore PE, Hart CA, Samuel JD, Ramani VA, George NJ, Clarke NW (2007) Characterization of benign and malignant prostate epithelial Hoechst 33342 side populations. Prostate 67(13):1384-1396. doi:10.1002/pros.20620

Cai X, Hagedorn CH, Cullen BR (2004) Human microRNAs are processed from capped, polyadenylated transcripts that can also function as mRNAs. RNA (New York, NY) 10(12):1957-1966. doi:10.1261/rna.7135204 
Calin GA, Sevignani C, Dumitru CD, Hyslop T, Noch E, Yendamuri S, Shimizu M, Rattan S, Bullrich F, Negrini M, Croce CM (2004) Human microRNA genes are frequently located at fragile sites and genomic regions involved in cancers. Proc Natl Acad Sci USA 101(9):2999-3004. doi:10.1073/pnas.0307323101

Chen F, Hu SJ (2012) Effect of microRNA-34a in cell cycle, differentiation, and apoptosis: a review. J Biochem Mol Toxicol 26(2):79-86. doi:10.1002/ jbt.20412

Chen DQ, Huang JY, Feng B, Pan BZ, De W, Wang R, Chen LB (2014) Histone deacetylase 1/Sp1/microRNA-200b signaling accounts for maintenance of cancer stem-like cells in human lung adenocarcinoma. PLoS One 9(10):e109578. doi:10.1371/journal.pone.0109578

Chhabra R, Saini N (2014) MicroRNAs in cancer stem cells: current status and future directions. Tumour Biol J Int Soc Oncodev Biol Med 35(9):83958405. doi:10.1007/s13277-014-2264-7

Chiou GY, Cherng JY, Hsu HS, Wang ML, Tsai CM, Lu KH, Chien Y, Hung SC, Chen YW, Wong Cl, Tseng LM, Huang PI, Yu CC, Hsu WH, Chiou SH (2012) Cationic polyurethanes-short branch PEl-mediated delivery of Mir145 inhibited epithelial-mesenchymal transdifferentiation and cancer stem-like properties and in lung adenocarcinoma. J Control Rel Off J Control Rel Soc 159(2):240-250. doi:10.1016/j. jconrel.2012.01.014

Chivukula RR, Mendell JT (2008) Circular reasoning: microRNAs and cellcycle control. Trends Biochem Sci 33(10):474-481. doi:10.1016/j. tibs.2008.06.008

Cho WC, Chow AS, Au JS (2011) MiR-145 inhibits cell proliferation of human lung adenocarcinoma by targeting EGFR and NUDT1. RNA Biol $8(1): 125-131$

Comijn J, Berx G, Vermassen P, Verschueren K, van Grunsven L, Bruyneel E, Mareel M, Huylebroeck D, van Roy F (2001) The two-handed E box binding zinc finger protein SIP1 downregulates E-cadherin and induces invasion. Mol Cell 7(6):1267-1278

Dai X, Ge J, Wang X, Qian X, Zhang C, Li X (2013) OCT4 regulates epithelialmesenchymal transition and its knockdown inhibits colorectal cancer cell migration and invasion. Oncol Rep 29(1):155-160. doi:10.3892/ or.2012.2086

DeSano JT, Xu L (2009) MicroRNA regulation of cancer stem cells and therapeutic implications. AAPS J 11(4):682-692. doi:10.1208/ s12248-009-9147-7

D'Ippolito E, lorio MV (2013) MicroRNAs and triple negative breast cancer. Int J Mol Sci 14(11):22202-22220. doi:10.3390/ijms141122202

Dumortier O, Hinault C, Van Obberghen E (2013) MicroRNAs and metabolism crosstalk in energy homeostasis. Cell Metab 18(3):312-324. doi:10.1016/j.cmet.2013.06.004

Esau C, Kang X, Peralta E, Hanson E, Marcusson EG, Ravichandran LV, Sun Y, Koo S, Perera RJ, Jain R, Dean NM, Freier SM, Bennett CF, Lollo B, Griffey R (2004) MicroRNA-143 regulates adipocyte differentiation. J Biol Chem 279(50):52361-52365. doi:10.1074/jbc.C400438200

Fabian MR, Sonenberg N (2012) The mechanics of miRNA-mediated gene silencing: a look under the hood of miRISC. Nat Struct Mol Biol 19(6):586-593. doi:10.1038/nsmb.2296

Feng B, Wang R, Song HZ, Chen LB (2012) MicroRNA-200b reverses chemoresistance of docetaxel-resistant human lung adenocarcinoma cells by targeting E2F3. Cancer 118(13):3365-3376. doi:10.1002/cncr.26560

Ferlay J, Parkin DM, Steliarova-Foucher E (2010) Estimates of cancer incidence and mortality in Europe in 2008. Eur J Cancer (Oxford, England : 1990) 46(4):765-781. doi:10.1016/j.ejca.2009.12.014

Frost RJ, Olson EN (2011) Control of glucose homeostasis and insulin sensitivity by the Let-7 family of microRNAs. Proc Natl Acad Sci USA 108(52):21075-21080. doi:10.1073/pnas.1118922109

Garzon R, Pichiorri F, Palumbo T, Visentini M, Aqeilan R, Cimmino A, Wang $\mathrm{H}$, Sun H, Volinia S, Alder H, Calin GA, Liu CG, Andreeff M, Croce CM (2007) MicroRNA gene expression during retinoic acid-induced differentiation of human acute promyelocytic leukemia. Oncogene 26(28):4148-4157. doi:10.1038/sj.onc.1210186

Garzon R, Calin GA, Croce CM (2009) MicroRNAs in cancer. Annu Rev Med 60:167-179. doi:10.1146/annurev.med.59.053006.104707

Gilad S, Meiri E, Yogev Y, Benjamin S, Lebanony D, Yerushalmi N, Benjamin H, Kushnir M, Cholakh H, Melamed N, Bentwich Z, Hod M, Goren Y, Chajut A (2008) Serum microRNAs are promising novel biomarkers. PLoS One 3(9):e3148. doi:10.1371/journal.pone.0003148
Gregory PA, Bert AG, Paterson EL, Barry SC, Tsykin A, Farshid G, Vadas MA, Khew-Goodall Y, Goodall GJ (2008) The miR-200 family and miR-205 regulate epithelial to mesenchymal transition by targeting ZEB1 and SIP1. Nat Cell Biol 10(5):593-601. doi:10.1038/ncb1722

Grimson A, Farh KK, Johnston WK, Garrett-Engele P, Lim LP, Bartel DP (2007) MicroRNA targeting specificity in mammals: determinants beyond seed pairing. Mol Cell 27(1):91-105. doi:10.1016/j.molcel.2007.06.017

He C, Xiong J, Xu X, Lu W, Liu L, Xiao D, Wang D (2009) Functional elucidation of MiR-34 in osteosarcoma cells and primary tumor samples. Biochem Biophys Res Commun 388(1):35-40. doi:10.1016/j.bbrc.2009.07.101

Hermann PC, Huber SL, Herrler T, Aicher A, Ellwart JW, Guba M, Bruns CJ, Heeschen C (2007) Distinct populations of cancer stem cells determine tumor growth and metastatic activity in human pancreatic cancer. Cell Stem Cell 1(3):313-323. doi:10.1016/j.stem.2007.06.002

Ho MM, Ng AV, Lam S, Hung JY (2007) Side population in human lung cancer cell lines and tumors is enriched with stem-like cancer cells. Cancer Res 67(10):4827-4833. doi:10.1158/0008-5472.can-06-3557

Hollis M, Nair K, Vyas A, Chaturvedi LS, Gambhir S, Vyas D (2015) MicroRNAs potential utility in colon cancer: early detection, prognosis, and chemosensitivity. World J Gastroenterol 21(27):8284-8292. doi:10.3748/wjg. V21.i27.8284

Hu J, Qiu M, Jiang F, Zhang S, Yang X, Wang J, Xu L, Yin R (2014) MiR-145 regulates cancer stem-like properties and epithelial-to-mesenchymal transition in lung adenocarcinoma-initiating cells. Tumour Biol J Int Soc Oncodev Biol Med 35(9):8953-8961. doi:10.1007/ s13277-014-2158-8

Hua S, Xiaotao X, Renhua G, Yongmei Y, Lianke L, Wen G, Yongqian S (2012) Reduced miR-31 and let-7 maintain the balance between differentiation and quiescence in lung cancer stem-like side population cells. Biomed Pharmacother 66(2):89-97. doi:10.1016/j.biopha.2011.09.013

Hung WC, Shau MD, Kao HC, Shih MF, Cherng JY (2009) The synthesis of cationic polyurethanes to study the effect of amines and structures on their DNA transfection potential. J Control Rel Off J Control Release Society 133(1):68-76. doi:10.1016/j.jconrel.2008.09.082

Hwang HW, Mendell JT (2006) MicroRNAs in cell proliferation, cell death, and tumorigenesis. Br J Cancer 94(6):776-780. doi:10.1038/sj.bjc.6603023

Iliopoulos D, Lindahl-Allen M, Polytarchou C, Hirsch HA, Tsichlis PN, Struhl K (2010) Loss of miR-200 inhibition of Suz12 leads to polycomb-mediated repression required for the formation and maintenance of cancer stem cells. Mol Cell 39(5):761-772. doi:10.1016/j.molcel.2010.08.013

Johnson SM, Grosshans H, Shingara J, Byrom M, Jarvis R, Cheng A, Labourier E, Reinert KL, Brown D, Slack FJ (2005) RAS is regulated by the let-7 microRNA family. Cell 120(5):635-647. doi:10.1016/j.cell.2005.01.014

Johnson CD, Esquela-Kerscher A, Stefani G, Byrom M, Kelnar K, Ovcharenko D, Wilson M, Wang X, Shelton J, Shingara J, Chin L, Brown D, Slack FJ (2007) The let-7 microRNA represses cell proliferation pathways in human cells. Cancer Res 67(16):7713-7722. doi:10.1158/0008-5472.can-07-1083

Joshi P, Middleton J, Jeon YJ, Garofalo M (2014) MicroRNAs in lung cancer. World J Methodol 4(2):59-72. doi:10.5662/wjm.v4.i2.59

Kalluri R, Weinberg RA (2009) The basics of epithelial-mesenchymal transition. J Clin Investig 119(6):1420-1428. doi:10.1172/jci39104

Kishikawa T, Otsuka M, Ohno M, Yoshikawa T, Takata A, Koike K (2015) Circulating RNAs as new biomarkers for detecting pancreatic cancer. World J Gastroenterol 21(28):8527-8540. doi:10.3748/wjg.v21.i28.8527

Kondo T, Setoguchi T, Taga T (2004) Persistence of a small subpopulation of cancer stem-like cells in the C6 glioma cell line. Proc Natl Acad Sci USA 101(3):781-786. doi:10.1073/pnas.0307618100

Kuppusamy KT, Jones DC, Sperber H, Madan A, Fischer KA, Rodriguez ML, Pabon L, Zhu WZ, Tulloch NL, Yang X, Sniadecki NJ, Laflamme MA, Ruzzo WL (2015) Let-7 family of microRNA is required for maturation and adult-like metabolism in stem cell-derived cardiomyocytes. Proc Natl Acad Sci 112(21):2785-2794. doi:10.1073/pnas.1424042112

Kurisetty VV, Lakshmanaswamy R, Damodaran C (2014) Pathogenic and therapeutic role of miRNAs in breast cancer. Front Biosci (Landmark edition) 19:1-11

Landgraf P, Rusu M, Sheridan R, Sewer A, lovino N, Aravin A, Pfeffer S, Rice A, Kamphorst AO, Landthaler M, Lin C, Socci ND, Hermida L, Fulci V, Chiaretti S, Foa R, Schliwka J, Fuchs U, Novosel A, Muller RU, Schermer B, Bissels U, Inman J, Phan Q, Chien M, Weir DB, Choksi R, De Vita G, Frezzetti D, Trompeter HI, Hornung V, Teng G, Hartmann G, Palkovits M, Di Lauro R, Wernet P, Macino G, Rogler CE, Nagle JW, Ju J, Papavasiliou 
FN, Benzing T, Lichter P, Tam W, Brownstein MJ, Bosio A, Borkhardt A, Russo JJ, Sander C, Zavolan M, Tuschl T (2007) A mammalian microRNA expression atlas based on small RNA library sequencing. Cell 129(7):1401-1414. doi:10.1016/j.cell.2007.04.040

Larderet G, Fortunel NO, Vaigot P, Cegalerba M, Maltere P, Zobiri O, Gidrol X, Waksman G, Martin MT (2006) Human side population keratinocytes exhibit long-term proliferative potential and a specific gene expression profile and can form a pluristratified epidermis. Stem cells (Dayton, Ohio) 24(4):965-974. doi:10.1634/stemcells.2005-0196

Lee RC, Feinbaum RL, Ambros V (1993) The C. elegans heterochronic gene lin-4 encodes small RNAs with antisense complementarity to lin-14. Cell 75(5):843-854

Lee Y, Kim M, Han J, Yeom KH, Lee S, Baek SH, Kim VN (2004) MicroRNA genes are transcribed by RNA polymerase II. EMBO J 23(20):4051-4060. doi:10.1038/sj.emboj.7600385

Li Y, Guessous F, Zhang Y, Dipierro C, Kefas B, Johnson E, Marcinkiewicz L, Jiang J, Yang Y, Schmittgen TD, Lopes B, Schiff D, Purow B, Abounader R (2009) MicroRNA-34a inhibits glioblastoma growth by targeting multiple oncogenes. Cancer Res 69(19):7569-7576. doi:10.1158/0008-5472. can-09-0529

Lin S, Sun JG, Wu JB, Long HX, Zhu CH, Xiang T, Ma H, Zhao ZQ, Yao Q, Zhang AM, Zhu B, Chen ZT (2012) Aberrant microRNAs expression in CD133(+)/CD326(+) human lung adenocarcinoma initiating cells from A549. Mol Cells 33(3):277-283. doi:10.1007/s10059-012-2252-y

Liu C, Tang DG (2011) MicroRNA regulation of cancer stem cells. Cancer Res 71(18):5950-5954. doi:10.1158/0008-5472.can-11-1035

Liu XY, Ho WY, Hung WJ, Shau MD (2009) The characteristics and transfection efficiency of cationic poly (ester-co-urethane) - short chain PEI conjugates self-assembled with DNA. Biomaterials 30(34):6665-6673. doi:10.1016/j.biomaterials.2009.08.052

Liu X, Sempere LF, Ouyang H, Memoli VA, Andrew AS, Luo Y, Demidenko E, Korc M, Shi W, Preis M, Dragnev KH, Li H, Direnzo J, Bak M, Freemantle SJ, Kauppinen S, Dmitrovsky E (2010) MicroRNA-31 functions as an oncogenic microRNA in mouse and human lung cancer cells by repressing specific tumor suppressors. J Clin Investig 120(4):1298-1309. doi:10.1172/jci39566

Liu C, Kelnar K, Liu B, Chen X, Calhoun-Davis T, Li H, Patrawala L, Yan H, Jeter C, Honorio S, Wiggins JF, Bader AG, Fagin R, Brown D, Tang DG (2011) The microRNA miR-34a inhibits prostate cancer stem cells and metastasis by directly repressing CD44. Nat Med 17(2):211-215. doi:10.1038/ nm.2284

Lobo NA, Shimono Y, Qian D, Clarke MF (2007) The biology of cancer stem cells. Annu Rev Cell Dev Biol 23:675-699. doi:10.1146/annurev. cellbio.22.010305.104154

Lu J, Getz G, Miska EA, Alvarez-Saavedra E, Lamb J, Peck D, Sweet-Cordero A, Ebert BL, Mak RH, Ferrando AA, Downing JR, Jacks T, Horvitz HR, Golub TR (2005) MicroRNA expression profiles classify human cancers. Nature 435(7043):834-838. doi:10.1038/nature03702

Lu R, Ji Z, Li X, Zhai Q, Zhao C, Jiang Z, Zhang S, Nie L, Yu Z (2014) miR-145 functions as tumor suppressor and targets two oncogenes, ANGPT2 and NEDD9, in renal cell carcinoma. J Cancer Res Clin Oncol 140(3):387397. doi:10.1007/s00432-013-1577-z

Mackillop WJ, Ciampi A, Till JE, Buick RN (1983) A stem cell model of human tumor growth: implications for tumor cell clonogenic assays. J Natl Cancer Inst 70(1):9-16

Mayr C, Hemann MT, Bartel DP (2007) Disrupting the pairing between let-7 and Hmga2 enhances oncogenic transformation. Science (New York, NY) 315(5818):1576-1579. doi:10.1126/science.1137999

Misso G, Di Martino MT, De Rosa G, Farooqi AA, Lombardi A, Campani V, Zarone MR, Gulla A, Tagliaferri P, Tassone P, Caraglia M (2014) Mir-34: a new weapon against cancer? Mol Therapy Nucleic Acids 3:e194. doi:10.1038/ mtna.2014.47

Ohashi S, Natsuizaka M, Naganuma S, Kagawa S, Kimura S, Itoh H, Kalman RA, Nakagawa M, Darling DS, Basu D, Gimotty PA, Klein-Szanto AJ, Diehl JA, Herlyn M, Nakagawa H (2011) A NOTCH3-mediated squamous cell differentiation program limits expansion of EMT-competent cells that express the ZEB transcription factors. Cancer Res 71(21):6836-6847. doi:10.1158/0008-5472.can-11-0846

Pang R, Law WL, Chu AC, Poon JT, Lam CS, Chow AK, Ng L, Cheung LW, Lan XR, Lan HY, Tan VP, Yau TC, Poon RT, Wong BC (2010a) A subpopulation of
CD26 + cancer stem cells with metastatic capacity in human colorectal cancer. Cell Stem Cell 6(6):603-615. doi:10.1016/j.stem.2010.04.001

Pang RT, Leung CO, Ye TM, Liu W, Chiu PC, Lam KK, Lee KF, Yeung WS (2010b) MicroRNA-34a suppresses invasion through downregulation of Notch1 and Jagged 1 in cervical carcinoma and choriocarcinoma cells. Carcinogenesis 31(6):1037-1044. doi:10.1093/carcin/bgq066

Pang Y, Young CY, Yuan H (2010c) MicroRNAs and prostate cancer. Acta Biochim Biophys $\operatorname{Sin} 42(6): 363-369$

Papagiannis A (2004) Multidisciplinary management of lung cancer. New Engl J Med 350(19):2008-2010 (author reply 2008-2010)

Park SM, Gaur AB, Lengyel E, Peter ME (2008) The miR-200 family determines the epithelial phenotype of cancer cells by targeting the E-cadherin repressors ZEB1 and ZEB2. Genes Dev 22(7):894-907. doi:10.1101/gad.1640608

Pauli A, Rinn JL, Schier AF (2011) Non-coding RNAs as regulators of embryogenesis. Nat Rev Genet 12(2):136-149. doi:10.1038/nrg2904

Peng CH, Cherng JY, Chiou GY, Chen YC, Chien CH, Kao CL, Chang YL, Chien Y, Chen LK, Liu JH, Chen SJ, Chiou SH (2011) Delivery of Oct4 and SirT1 with cationic polyurethanes-short branch PEl to aged retinal pigment epithelium. Biomaterials 32(34):9077-9088. doi:10.1016/j.biomaterials.2011.08.008

Perera RJ, Ray A (2007) MicroRNAs in the search for understanding human diseases. BioDrugs: clinical immunotherapeutics, biopharmaceuticals and gene therapy 21(2):97-104

Pirozzi G, Tirino V, Camerlingo R, Franco R, La Rocca A, Liguori E, Martucci N, Paino F, Normanno N, Rocco G (2011) Epithelial to mesenchymal transition by TGFbeta-1 induction increases stemness characteristics in primary non small cell lung cancer cell line. PLoS One 6(6):e21548. doi:10.1371/journal.pone.0021548

Poellinger L, Lendahl U (2008) Modulating Notch signaling by pathwayintrinsic and pathway-extrinsic mechanisms. Curr Opin Genet Dev 18(5):449-454. doi:10.1016/j.gde.2008.07.013

Rachagani S, Kumar S, Batra SK (2010) MicroRNA in pancreatic cancer: pathological, diagnostic and therapeutic implications. Cancer Lett 292(1):8-16. doi:10.1016/..canlet.2009.11.010

Reinhart BJ, Slack FJ, Basson M, Pasquinelli AE, Bettinger JC, Rougvie AE, Horvitz HR, Ruvkun G (2000) The 21-nucleotide let-7 RNA regulates developmental timing in Caenorhabditis elegans. Nature 403(6772):901-906. doi:10.1038/35002607

Rinn JL, Chang HY (2012) Genome regulation by long noncoding RNAs. Annu Rev Biochem 81:145-166. doi:10.1146/ annurev-biochem-051410-092902

Sampson VB, Rong NH, Han J, Yang Q, Aris V, Soteropoulos P, Petrelli NJ, Dunn SP, Krueger LJ (2007) MicroRNA let-7a down-regulates MYC and reverts MYC-induced growth in Burkitt lymphoma cells. Cancer Res 67(20):9762-9770. doi:10.1158/0008-5472.can-07-2462

Serpico D, Molino L, Di Cosimo S (2014) MicroRNAs in breast cancer development and treatment. Cancer Treat Rev 40(5):595-604. doi:10.1016/j. ctrv.2013.11.002

Shi Y, Liu C, Liu X, Tang DG, Wang J (2014) The microRNA miR-34a inhibits non-small cell lung cancer (NSCLC) growth and the CD44hi stem-like NSCLC cells. PLoS One 9(3):e90022. doi:10.1371/journal. pone.0090022

Sun L, Yao Y, Liu B, Lin Z, Lin L, Yang M, Zhang W, Chen W, Pan C, Liu Q, Song E, Li J (2012) MiR-200b and miR-15b regulate chemotherapy-induced epithelial-mesenchymal transition in human tongue cancer cells by targeting BMI1. Oncogene 31(4):432-445. doi:10.1038/onc.2011.263

Szotek PP, Pieretti-Vanmarcke R, Masiakos PT, Dinulescu DM, Connolly D, Foster R, Dombkowski D, Preffer F, Maclaughlin DT, Donahoe PK (2006) Ovarian cancer side population defines cells with stem cell-like characteristics and Mullerian Inhibiting Substance responsiveness. Proc Natl Acad Sci USA 103(30):11154-11159. doi:10.1073/pnas.0603672103

Thiery JP (2002) Epithelial-mesenchymal transitions in tumour progression. Nat Rev Cancer 2(6):442-454. doi:10.1038/nrc822

Valastyan S, Weinberg RA (2010) miR-31: a crucial overseer of tumor metastasis and other emerging roles. Cell cycle (Georgetown, Tex) 9(11):2124-2129

Valastyan S, Benaich N, Chang A, Reinhardt F, Weinberg RA (2009a) Concomitant suppression of three target genes can explain the impact of a microRNA on metastasis. Genes Dev 23(22):2592-2597. doi:10.1101/ gad. 1832709

Valastyan S, Reinhardt F, Benaich N, Calogrias D, Szasz AM, Wang ZC, Brock JE, Richardson AL, Weinberg RA (2009b) A pleiotropically acting microRNA, 
miR-31, inhibits breast cancer metastasis. Cell 137(6):1032-1046 doi:10.1016/j.cell.2009.03.047

Vasudevan S, Tong Y, Steitz JA (2007) Switching from repression to activation: microRNAs can up-regulate translation. Science (New York, NY) 318(5858):1931-1934. doi:10.1126/science.1149460

Wang Z, Zhang Y, Li Y, Banerjee S, Liao J, Sarkar FH (2006) Down-regulation of Notch-1 contributes to cell growth inhibition and apoptosis in pancreatic cancer cells. Mol Cancer Ther 5(3):483-493. doi:10.1158/1535-7163. mct-05-0299

Wang X, Dong K, Gao P, Long M, Lin F, Weng Y, Ouyang Y, Ren J, Zhang H (2013a) microRNA-34a sensitizes lung cancer cell lines to DDP treatment independent of p53 status. Cancer biotherapy \& radiopharmaceuticals 28(1):45-50. doi:10.1089/cbr.2012.1218

Wang X, Lu H, Li T, Yu L, Liu G, Peng X, Zhao J (2013b) Kruppel-like factor 8 promotes tumorigenic mammary stem cell induction by targeting miR146a. Am J Cancer Res 3(4):356-373

Wiggins JF, Ruffino L, Kelnar K, Omotola M, Patrawala L, Brown D, Bader AG (2010) Development of a lung cancer therapeutic based on the tumor suppressor microRNA-34. Cancer Res 70(14):5923-5930. doi:10.1158/0008-5472.can-10-0655

Winter J, Jung S, Keller S, Gregory RI, Diederichs S (2009) Many roads to maturity: microRNA biogenesis pathways and their regulation. Nat Cell Biol 11(3):228-234. doi:10.1038/ncb0309-228

Wszolek MF, Rieger-Christ KM, Kenney PA, Gould JJ, Silva Neto B, Lavoie AK, Logvinenko T, Libertino JA, Summerhayes IC (2011) A MicroRNA expression profile defining the invasive bladder tumor phenotype. Urol Oncol 29(6):794-801.e791. doi:10.1016/j.urolonc.2009.08.024
Wu Z, Wu Y, Tian Y, Sun X, Liu J, Ren H, Liang C, Song L, Hu H, Wang L, Jiao B (2013) Differential effects of miR-34c-3p and miR-34c-5p on the proliferation, apoptosis and invasion of glioma cells. Oncol Lett 6(5):14471452. doi:10.3892/ol.2013.1579

Yan K, Gao J, Yang T, Ma Q, Qiu X, Fan Q, Ma B (2012) MicroRNA-34a inhibits the proliferation and metastasis of osteosarcoma cells both in vitro and in vivo. PLoS One 7(3):e33778. doi:10.1371/journal.pone.0033778

Yang S, Li Y, Gao J, Zhang T, Li S, Luo A, Chen H, Ding F, Wang X, Liu Z (2013) MicroRNA-34 suppresses breast cancer invasion and metastasis by directly targeting Fra-1. Oncogene 32(36):4294-4303. doi:10.1038/ onc.2012.432

Yin R, Zhang S, Wu Y, Fan X, Jiang F, Zhang Z, Feng D, Guo X, Xu L (2011) microRNA-145 suppresses lung adenocarcinoma-initiating cell proliferation by targeting OCT4. Oncol Rep 25(6):1747-1754. doi:10.3892/ or.2011.1252

Zhang S, Wu Y, Feng D, Zhang Z, Jiang F, Yin R, Xu L (2011) miR-145 inhibits lung adenocarcinoma stem cells proliferation by targeting OCT4 gene. Chin J Lung Cancer 14(4):317-322. doi:10.3779/j. issn.1009-3419.2011.04.03

Zhao C, Sun G, Li S, Lang MF, Yang S, Li W, Shi Y (2010) MicroRNA let-7b regulates neural stem cell proliferation and differentiation by targeting nuclear receptor TLX signaling. Proc Natl Acad Sci USA 107(5):18761881. doi:10.1073/pnas.0908750107

Zhu H, Shyh-Chang N, Segre AV, Shinoda G, Shah SP, Einhorn WS, Takeuchi A, Engreitz JM, Hagan JP, Kharas MG, Urbach A, Thornton JE, Triboulet R, Gregory RI, Altshuler D, Daley GQ (2011) The Lin28/let-7 axis regulates glucose metabolism. Cell 147(1):81-94. doi:10.1016/j.cell.2011.08.033

\section{Submit your manuscript to a SpringerOpen ${ }^{\circ}$ journal and benefit from:}

- Convenient online submission

- Rigorous peer review

- Immediate publication on acceptance

- Open access: articles freely available online

- High visibility within the field

- Retaining the copyright to your article

Submit your next manuscript at $\boldsymbol{\nabla}$ springeropen.com 